\title{
Pengembangan Perangkat Penilaian Hasil Belajar dalam Pembelajaran Tematik- Integratif Kelas V SD
}

\author{
Teguh Prasetyo \\ PGSD FKIP Universitas Djuanda Bogor, Jalan Tol Ciawi No.01 Ciawi Bogor 16720, Indonesia \\ Korespondensi Penulis. Email: teguh.dikdas@gmail.com \\ Received: 15 December 2015; Revised:8 August 2016; Accepted: 19 September 2016
}

\begin{abstract}
Abstrak
Penelitian ini bertujuan untuk: (1) menghasilkan perangkat penilaian yang layak untuk pembelajaran tematik-integratif kelas V SD, (2) mengetahui kepraktisan perangkat penilaian yang dikembangkan, dan (3) mengetahui keefektifan perangkat penilaian di kelas V SD pada subtema Komponen Ekosistem. Penelitian pengembangan ini mengacu pada model pengembangan 4-D dari Thiagarajan, Semmel, \& Semmel yang telah dimodifikasi menjadi tiga prosedur pengembangan, yaitu: (1) define, (2) design, dan (3) develop. Subjek uji coba pengembangan terdiri dari SDN Godean 1, SDN Cebongan 1, dan SDN Purwomartani. Hasil penelitian menunjukkan bahwa perangkat penilaian hasil belajar dalam pembelajaran tematik-integratif di kelas V SD pada subtema Komponen Ekosistem layak digunakan, praktis, dan efektif. Selain itu produk juga dapat mengukur ketuntasan prestasi belajar peserta didik.
\end{abstract}

Kata Kunci: perangkat penilaian, pembelajaran tematik integratif, sekolah dasar

\section{Developing Assessment Kits of Learning Outcomes on Thematic-Integrated Learning in Class $V$ of Elementary Schools}

\begin{abstract}
This study aims to: (1) produce a feasible assessment kits for thematic integrated learning in class V SD, (2) determine the practicality of assessment kits developed, and (3) determine the effectiveness of assessment kits in class V SD in subtheme Ecosystem Components. The research refers to the 4-D model of the development of Thiagarajan, Semmel, \& Semmel which has been modified into three procedures of development, namely: (1) define, (2) design, and (3) develop. The trial development subject consists of SDN Godean 1, SDN Cebongan 1, and SDN Purwomartani. The results show that the assessment kits of learning outcomes in thematic-integrative learning in class $V$ $S D$ in subtema Ecosystem Components are appropriate, practical, and effective. In addition, the product can also measure mastery learning achievements of learners.
\end{abstract}

Keywords: assessment kits, thematic integrative learning, elementary school

How to Cite: Prasetyo, T. (2017). Pengembangan perangkat penilaian hasil belajar dalam pembelajaran tematik integratif kelas V SD.Jurnal Prima Edukasia, 5(1), 102-111. doi:http://dx.doi.org/10.21831/jpe.v5i1.7528

Permalink/ DOI: http://dx.doi.org/10.21831/jpe.v5i1.7528 


\section{Pendahuluan}

Kurikulum 2013 pada tingkat pendidikan Sekolah Dasar (SD) mengalami perubahan yang mendasar terutama kompetensi yang semula diturunkan dari mata pelajaran berubah menjadi mata pelajaran yang dikembangkan dari kompetensi. Selanjutnya beberapa mata pelajaran dihilangkan dan diintegrasikan ke dalam pembelajaran yang berdasarkan tema, sehingga pembelajaran yang dilakukan di kelas pembelajaran tematik integratif (thematic integrated). Pada Kurikulum 2006 pembelajaran tematik integratif hanya diterapkan di kelas rendah 1-3 sedangkan kelas 4-6 masih menerapkan pembelajaran per mata pelajaran. Pada Kurikulum 2013 pembelajaran tematik-integratif dilaksanakan dari kelas rendah sampai kelas tinggi.

Perubahan Kurikulum 2013 ini tentu saja mempengaruhi proses pembelajaran peserta didik yang dilaksanakan di kelas. Proses pembelajaran dilaksanakan melalui pendekatan saintifik dilakukan melalui tahapan mengamati, menanya, mengolah informasi, menalar, dan mengomunikasikan. Pembelajaran dapat dilaksanakan dimana saja tidak hanya terjadi di ruang kelas, tetapi juga di lingkungan sekolah dan masyarakat sehingga aktivitas peserta didik lebih menonjol dibandingkan guru. Guru bukan satu-satunya sebagai sumber belajar tetapi menjadi fasilitator dan motivator dalam segala bentuk kegiatan belajar peserta didik sehingga guru harus mampu menyiapkan proses pembelajaran yang tepat.

Pembelajaran tematik integratif di SD dilaksanakan melalui pendekatan saintifik memiliki relevansi yang kuat akan proses penilaian yang sebenarnya atau autentik. Hal ini didukung oleh Permendikbud Nomor 66 Tahun 2013 menyatakan "penilaian hasil belajar dilakukan dalam bentuk penilaian otentik, penilaian diri, penilaian projek, ulangan harian, ulangan tengah semester, ulangan akhir semester, ujian tingkat kompetensi, ujian mutu tingkat kompetensi, ujian sekolah, dan ujian nasional". Karena itu, penilaian autentik dipandang mampu menggambarkan peningkatan hasil belajar peserta didik baik dalam rangka mengobservasi, menalar, mencoba, membangun jejaring, dan lain-lain (Majid, 2014, p.239).

Menurut Apriani \& Wangid (2015, p.24) pembelajaran tematik memberikan proses pembelajaran yang mengajarkan tentang konsep, pengetahuan, dan keterampilan yang berkaitan dengan pengembangan estetika, keterampilan afektif, kognitif, bahasa, keterampilan fisik, keterampilan sosial, keterampilan konstruksi, dan keterampilan bermain. Oleh karena itu pembelajaran tematik sangat cocok untuk pembelajaran yang mengembangkan kompetensi sikap, pengetahuan dan keterampilan.

Penilaian hasil belajar pada Kurikulum 2013 merupakan penilaian yang dilaksanakan secara autentik untuk mengukur kompetensi inti sikap spiritual (KI-1) dan sikap sosial (KI-2), kompetensi inti pengetahuan (KI-3), dan kompetensi inti keterampilan (KI-4) yang dimiliki peserta didik. Untuk itu penting bagi guru memiliki keterampilan, pemahaman, dan persepsi yang baik tentang penilaian pembelajaran. Keterampilan guru dalam menyusun perangkat penilaian dapat membantu untuk memilih dan menentukan teknik penilaian mana yang digunakan.

Kebutuhan perangkat penilaian dalam pembelajaran sangat penting bagi guru karena hal itu dapat membantu guru untuk mengevaluasi keefektifan pembelajaran yang dilaksanakan. Earl \& Giles $(2011$, p.18) mengemukakan bahwa "guru perlu memiliki pengetahuan profesional untuk mengetahui proses penilaian". Keterampilan guru dalam praktek profesional melakukan pembelajaran dan menunjukkan cara profesional dalam penilaian di kelas. Lebih dari proses yang berkelanjutan, meningkatkan belajar peserta didik melalui praktik penilaian adalah proses diwujudkan yang muncul dari pembelajaran karena merupakan ruang relasional interaktif antara guru dan peserta didik.

Selanjutnya hasil analisis kebutuhan melalui observasi dan wawancara di SD piloting projek Kurikulum 2013 Kota Yogyakarta pada bulan Januari sampai Maret 2015. Adapun sekolah yang digunakan peneliti diantaranya SDN Cebongan 1 dan SDN Godean 1 ditemukan beberapa masalah. Permasalahan yang dialami guru terutama dalam melakukan proses penilaian hasil belajar, yaitu: (1) proses penilaian pembelajaran masih dilakukan secara parsial dalam pembelajaran di SD, (2) proses penilaian hasil belajar lebih fokus pada tes tertulis, (3) proses penilaian pada aspek sikap, pengetahuan, dan keterampilan yang dilakukan guru membutuhkan waktu yang lama, (4) belum ada perangkat penilaian yang dikembangkan praktis dan efektif di kelas V SD.

Arends (2010, p.19) mengemukakan bahwa guru yang efektif adalah yang dapat membangun interaksi dengan peserta didik, melalui bimbingan dan peduli terhadap lingkungan 
sekitar sekolah sedangkan definisi guru yang efektif adalah orang yang cinta mengajar, memahami pelajaran akademis tertentu, dan memampuan untuk memahami peserta didik. Guru yang efektif mempunyai penguasaan materi pelajaran, menggunakan strategi pembelajaran efektif tidak sekadar basa basi, bekerja dengan kelompok budaya dan etnis beragam, serta memiliki keterampilan bidang seperti; perencanaan dan penentuan tujuan, praktik mengajar yang sesuai, manajemen kelas, memotivasi, komunikasi, asesmen, dan teknologi

Selanjutnya pembelajaran Kurikulum 2013 di SD dilakukan dengan menggunakan pembelajaran tematik integratif. Maksudnya pembelajaran integratif, dimana kompetensikompetensi mata pelajaran yang dipadukan dan diikat dalam sebuah tema kemudian menjadi materi belajar bagi peserta didik di kelas. Pada proses pendekatan pembelajaran dilakukan melalui pendekatan saintifik (scientific approach), dimana peserta didik melakukan lima tahapan kegiatan yang diawali dari: (a) mengamati, (b) menanya, (c) mengumpulkan informasi, (d) mengasosiasikan, dan (e) mengomunikasikan hasil pembelajaran yang diperoleh (Kemendikbud, 2014, p.19).

Pembelajaran tematik di SD dikatakan bermakna karena dengan pembelajaran tematik, peserta didik akan memahami konsep-konsep yang dipelajari melalui pengalaman secara langsung dan menghubungkan dengan konsep lain yang telah dipahami. Menurut (Fogarty, 1991, p.76) model pembelajaran tematik integratif merupakan pemaduan sejumlah topik dari mata pelajaran yang berbeda, tetapi esensinya sama dalam sebuah topik tertentu. Lebih lanjut pembelajaran tematik integratif dalam diintegrasikan berbagai mata pelajaran melalui pendekatan yaitu intra-disipliner, inter-disipliner, multi-disipliner, dan trans-disipliner (Permendikbud No. 67 Tahun 2013).

Pembelajaran tematik integratif di kelas awal 1, 2, dan 3 lebih sering sering menggunakan pendekatan inter-disipliner, dimana untuk kemudahan pengorganisasian kompetensi dasar IPA dan IPS diintegrasikan ke mata pelajaran lain (misalnya ke dalam Bahasa Indonesia). Selanjutnya untuk pembelajaran tematik integratif di kelas 4, 5, dan 6 kompetensi dasar mata pelajaran IPA dan IPS masing-masing berdiri sendiri sehingga pendekatanya adalah multi-disipliner.

Penilaian pada dasarnya tidak dapat terpisahkan dari proses pembelajaran yang berlangsung di kelas. Namun, pada proses pelaksanaan di kelas sering kali proses penilaian diabaikan oleh guru alasannya karena penilaian dapat dilaksanakan setelah proses pembelajaran. Menurut Stiggins \& Chappuis (2012, p.30) penilaian untuk pembelajaran (assessmen for learning) sangat penting dalam pembelajaran. Proses penilaian merupakan proses yang sistematis dan terencana yang memainkan peran penting dalam pembelajaran yang efektif. Penilaian dimulai dengan identifikasi tujuan pembelajaran, memantau kemajuan siswa membuat arah tujuan pembelajaran, dan diakhiri dengan sebuah keputusan mengenai sejauh mana tujuan-tujuan tersebut telah dicapai oleh peserta didik.

Penilaian untuk pembelajaran, yakni penilaian mulai dari proses sampai pada pengecekan pembelajaran. Penilaian untuk pembelajaran termasuk pada penilaian formatif yang dapat digunakan untuk mendiagnosis kebutuhan belajar peserta didik dan membantu peserta didik untuk mencapai kesuksesan dalam belajar. Strategi-strategi pelaksanaan penilaian untuk pembelajaran (Stiggins \& Chappuis, 2012, p.30) meliputi (1) memberikan pemahaman yang jelas kepada peserta didik dan visi target belajar, (2) memberikan contoh dan model baik dari segi kekuatan dan kelemahan, (3) emberikan umpan balik secara deskriptif, (4) mengajarkan peserta didik untuk melakukan penilaian diri dan tujuan akhir, (5) desain belajar fokus pada tujuan belajar atau aspek kualitas waktu, (6) mengajarkan peserta didik untuk merevisi pekerjaannya menjadi salah satu kunci sebagai waktu.

AERA (Reynolds, Livingston, \& Willson, 2010, p.3) menyatakan bahwa "assessment is any systematic procedure for collecting information that can be used to make inferences about the characteristics of people or object". Penilaian hasil belajar merupakan prosedur yang dilakukan untuk memperoleh informasi peserta didik melalui proses pengukuran berupa tes dan nontes atau observasi informal. Jadi, pelaksanaan penilaian dipandang sangat penting bagi guru dalam proses pembelajaran karena dapat digunakan untuk meningkatkan kualitas pembelajaran, meningkatkan motivasi belajar peserta didik, memahami karakteristik dan kemajuan belajar peserta didik

Berdasarkan Permendikbud Nomor 104 Tahun 2014 penilaian hasil belajar memiliki tujuan untuk: (1) mengetahui tingkat penguasaan kompetensi dalam sikap, pengetahuan, dan 
keterampilan yang sudah dan belum dikuasai peserta didik untuk ditingkatkan dalam pembelajaran remedial dan program pengayaan; (2) menetapkan ketuntasan penguasaan kompetensi belajar peserta didik dalam kurun waktu tertentu, yaitu: harian, tengah semesteran, satu semesteran, satu tahunan, dan masa studi satuan pendidikan; (3) menetapkan program perbaikan atau pengayaan berdasarkan tingkat penguasaan kompetensi bagi mereka yang diidentifikasi sebagai peserta didik yang lambat; dan (4) memperbaiki proses pembelajaran pada pertemuan semester berikutnya.

Gronlund, Linn, \& Miller (2009, p.55) mengemukakan ada tiga ranah atau lingkup penilaian pembelajaran, yaitu: (1) domain kognitif, meliputi hasil pengetahuan, kemampuan intelektual, dan keterampilan, (2) domain afektif, meliputi sikap, minat, apresiasi, dan model penyesuain diri, dan (3) domain psikomotor meliputi persepsi dan keterampilan motorik. Pada Kurikulum 2013 lingkup penilaian hasil belajar mencakup kompetensi sikap terdiri atas sikap spiritual (KI-1), dan sikap sosial (KI-2), kompetensi pengetahuan atau KI-3 mencakup dimensi kognitif dan pengetahuan, dan kompetensi keterampilan atau KI-4 mencakup kemampuan belajar dan keterampilan konkret.

Perangkat penilaian pembelajaran merupakan salah satu komponen yang tidak dapat terpisahkan dalam proses pembelajaran di kelas. Menurut National Quality Council (2009, p.5) "an assessment tool is define as the instrumen(s) and procedures used to gather and interpret evidence of competence". Perangkat penilaian pembelajaran dapat dipahami dua hal yang saling melengkapi sebagai instrumen penilaian dan prosedur penggunaanya. Instrumen penilaian merupakan pertanyaan spesifik atau aktivitas yang digunakan untuk menilai kompetensi melalui pemilihan metode atau teknik penilaian sehingga memudahkan dalam mengambil keputusan. Instrumen penilaian ini sekaligus sebagai pedoman bagi guru atau penilai setiap penilaian kompetensi peserta didik.

Selanjutnya tema yang dikembangkan untuk perangkat penilaian adalah subtema Komponen Ekosistem kelas V SD. Adapun produk perangkat penilaian yang dikembangkan pada KD. IPA meliputi: (a) penilaian observasi sikap, (b) penilaian diri peserta didik, (c) penilaian tes uraian, dan (d) penilaian kinerja. Pengembangan penilaian observasi sikap berupa lembar observasi sikap spiritual (KI-) dan sikap sosial (KI-2) yang dilakukan untuk mengamati aktivitas peserta didik selama proses pembelajaran. Sehubungan dengan metode observasi, Anderson (2008, p.103) mengemukakan bahwa observasi formal dapat disamakan dengan dokumentasi. Observasi merupakan keperluan utama ketika guru menyandarkan keputusan tentang peserta didik secara individual dan dokumentasi digunakan untuk mendukung, mempertahankan, dan mengambil keputusan.

Penilaian diri peserta didik (self-assessment), merupakan salah satu bentuk penilaian sikap yang autentik, sebagaimana diungkapkan Anastasia \& Urbina (Reynolds, Livingston, \& Willson, 2010, p.383), "Self report is an instrumen completed by individuals that allows them to describe their own subjective experiences including emotional, motivational, interpersonal, and attitudinal charateristics". Penilaian diri sangat cocok untuk menilai kompetensi sikap diri peserta didik secara subyektif tentang karakteristik dan kepribadian yang dimiliki. Selanjutnya menurut Subali (2012, p.53) penilaian diri merupakan teknik dengan cara meminta peserta didik mengemukakan kelebihan dan kekurangan dirinya berkaitan dengan kompetensi yang menjadi tujuan pembelajaran.

Penilaian tes tertulis (paper and pencil test), merupakan penilaian tes yang sangat sering digunakan guru untuk mengetahui hasil belajar peserta didik setelah proses pembelajaran dilaksanakan. Mardapi (2012, p.108) menyatakan tujuan melakukan tes adalah untuk mengetahui pencapaian atau kompetensi yang telah dicapai peserta didik untuk bidang tertentu. Selanjutnya penilaian tertulis dapat dikelompokan ke dalam dua bentuk, yaitu tes objektif dan tes nonobjektif. Penelitian ini menggunakan tes esay, menurut Kubiszyn \& Borich (2010, p.163) keuntungan tes esay diantaranya, adalah: (1) most effective in assessing complex learning outcomes, (2) relatively easy to construct, (3) emphasize essential communication skill in complex academic disciplines, (4) guessing is eliminated.

Penilaian kinerja (performance assessment) sering disebut tes unjuk kerja karena pada umumnya menuntut unjuk kerja peserta didik berupa aktivitas demonstrasi secara langsung. Nitko \& Brookhart (2011, p.246) mengemukakan penilaian kinerja adalah: (a) meminta peserta didik untuk membuat produk atau mendemonstrasikan proses atau keduanya, (b) menggunakan definisi kriteria yang jelas untuk mengevaluasi hasil pekerjaan rumah peserta didik. Penilaian kinerja cocok digunakan untuk 


\section{Jurnal Prima Edukasia, 5 (1), January 2017 - 105}

Teguh Prasetyo

menilai ketercapaian kompetensi yang menuntut peserta didik melakukan tugas tertentu seperti: praktikum di laboratorium, praktik ibadah, praktik olahraga, presentasi, bermain peran, memainkan alat musik, bernyanyi, dan membaca puisi.

Penelitian dan pengembangkan ini bertujuan menghasilkan perangkat penilaian hasil belajar yang dapat digunakan untuk pembelajaran tematik integratif di kelas V SD. Selanjutnya perangkat penilaian hasil belajar yang dikembangkan harus memenuhi 3 kriteria, yaitu: layak, praktis, dan efektif. Perangkat penilaian hasil belajar yang digunakan layak digunakan berdasarkan hasil penilaian dari para ahli sedangkan kriteria praktis dan efektif berdasarkan hasil uji coba dan respon pengguna di lapangan.

\section{Metode}

Model pengembangan 4-D yang dikembangkan oleh Thiagarajan, Semmel, \& Semmel. Model ini terdiri atas empat tahap pengembangan yang kemudian dalam penelitian diadaptasi menjadi tiga tahapan, yaitu: tahap Define (pendefinisian), tahap Design (perancangan), dan tahap Develop (pengembangan). Penelitian dilaksanakan di SD piloting projek Kuriukulum 2013 Kabupaten Sleman. Waktu penelitian berlangsung selama tiga bulan, yaitu bulan Maret sampai Mei 2015 semester genap 2014/2015. Subjek penelitian ini adalah guru dan peserta didik SDN Cebongan 1, SDN Purwomartani 1, dan SDN Cebongan 1 tahun ajaran 2014/2015. Jumlah responden guru untuk uji coba terbatas sebanyak 1 orang dan 9 peserta didik sedangkan uji coba lapangan 3 guru dan 109 peserta didik.

Tahapan prosedur pengembangan meliputi tiga tahapan memodifikasi model pengembangan Thiagaran, Semmel, dan Semmel (1974), yaitu: (1) tahap define, (2) tahap design, dan (3) tahap develop. Prosedur pengembangan produk dapat dilihat pada Gambar 1.

Tahap define (pendefinisian) bertujuan untuk menentukan dan mendefinisikan perangkat penilaian hasil belajar yang dibutuhkan. Tahap ini berusaha menganalisis kebutuhan perangkat penilaian yang akan dikembangkan dan perlu menentukan batasan materi pembelajaran. Tahap design (perancangan) bertujuan mendesain prototipe perangkat penilaian yang akan dikembangkan. Pada tahap develop (pengembangan) produk perangkat penilaian hasil belajar dilakukan penilaian (expert judgement) oleh ahli dan selanjutnya dilaksanakan uji coba terbatas dan lapangan untuk mengetahui tingkat kepraktisan dan keefektifan produk.

Data penelitian ini dikumpulkan melalui instrumen penelitian yaitu: lembar wawancara, validasi ahli, observasi, dan angket. (1) Wawancara dilakukan untuk mengumpulkan analisis kebutuhan (need assessment) produk yang dikembang, (2) lembar validasi digunakan untuk memperoleh penilaian ahli terhadap kelayakan produk, (3) lembar observasi untuk mengamati keterlaksanaan produk dalam pembelajaran, dan (4) angket digunakan untuk mengumpulkan data kepraktisan produk berdasarkan respon guru dan peserta didik. Seluruh instrumen pengumpulan data telah divalidasi dan dinyatakan layak oleh ahli.

Analisis data dilakukan secara deskriptifkualitatif dengan memberikan narasi yang logis demi kepentingan penelitian. Analisis data dilakukan untuk memperoleh bukti perangkat penilaian yang dikembangkan telah memenuhi syarat layak, praktis, dan efektif.

Tabel 1. Interval Kelayakan Produk

\begin{tabular}{cc}
\hline Interval Skor Kelayakan & Kategori \\
\hline $94,5<\mathrm{X} \leq 116$ & Sangat Baik \\
$79,75<\mathrm{X} \leq 94,5$ & Baik \\
$65,25<\mathrm{X} 79,75$ & Cukup Baik \\
$50,75<\mathrm{X} \leq 65,25$ & Kurang Baik \\
$29 \leq \mathrm{X} \leq 50,75$ & Tidak Baik \\
\hline
\end{tabular}

Analisis data kelayakan produk diperoleh dari penilaian ahli terhadap perangkat penilaian hasil belajar yang dikembangkan, minimal produk layak dengan rentang skor 79,75-94,5 atau kategori baik. Selanjutnya untuk kriteria kepraktisan diperoleh dari respon guru dan peserta didik dalam menggunakan produk. Adapun interval skor kepraktisan produk berdasarkan respon guru.

Tabel 2. Interval Kepraktisan Produk

\begin{tabular}{cc}
\hline Interval Skor Kepraktisan & Kategori \\
\hline $22,75<\mathrm{X} \leq 28$ & Sangat Praktis \\
$19,25<\mathrm{X} \leq 22,75$ & Praktis \\
$15,75<\mathrm{X} 19,25$ & Cukup Praktis \\
$12,25<\mathrm{X} \leq 15,75$ & Kurang Praktis \\
$7 \leq \mathrm{X} \leq 12,25$ & Tidak Praktis \\
\hline
\end{tabular}

Tingkat kepraktisan produk yang dikembangkan dikatakan praktis bila mencapai skor 19,25-22,75 dengan kategori Praktis. Untuk respon peserta didik dikatakan positif bila $\geq$ $75 \%$ peserta didik menyatakan produk perangkat penilaian hasil belajar mudah digunakan, bahasa mudah dipahami, dan kemenarikan penampilan 


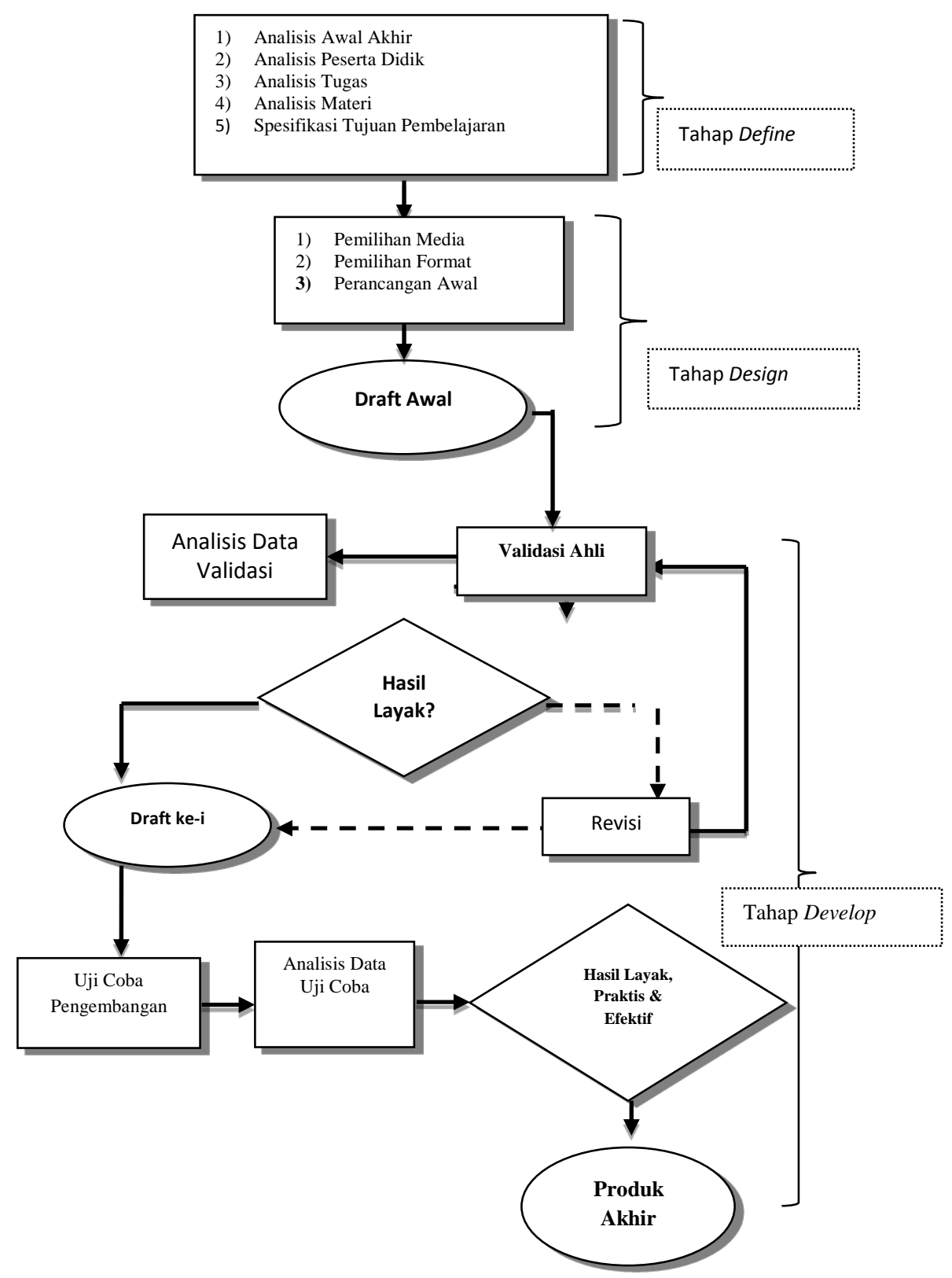

Gambar 1. Desain Prosedur Pengembangan

Tabel 3. Interval Skor Keterlaksanaan dan Aktivitas Peserta Didik

\begin{tabular}{ccc}
\hline $\begin{array}{c}\text { Interval Skor } \\
\text { Keterlaksanaa }\end{array}$ & $\begin{array}{c}\text { Interval Skor } \\
\text { Aktivitas }\end{array}$ & Kategori \\
\hline $48,75<\mathrm{X} \leq 60$ & $32,50<\mathrm{X} \leq 40$ & $\begin{array}{c}\text { Sangat } \\
\text { Efektif }\end{array}$ \\
$41,25<\mathrm{X} \leq 48,75$ & $27,50<\mathrm{X} \leq 32,50$ & Efektif \\
$33,75<\mathrm{X} 41,25$ & $22,50<\mathrm{X} 27,50$ & $\begin{array}{c}\text { Cukup } \\
\text { Efektif }\end{array}$ \\
$26,25<\mathrm{X} \leq 33,75$ & $14,50<\mathrm{X} \leq 22,50$ & $\begin{array}{c}\text { Kurang } \\
\text { Efektif }\end{array}$ \\
& & Tidak \\
$15 \leq \mathrm{X} \leq 26,25$ & $10 \leq \mathrm{X} \leq 14,50$ & Efektif \\
\hline
\end{tabular}

Pada kriteria keefektifan produk ditinjau dari observasi keterlaksanaan perangkat penilaian hasil belajar, observasi aktivitas peserta didik, dan ketuntasan penilaian prestasi belajar peserta didik mencakup kompetensi sikap spiritual (KI-1), sikap sosial (KI-2), pengetahuan (KI-3), dan keterampilan (KI-4). Adapun interval keterlaksanaan produk dan aktivitas peserta didik dapat disajikan pada Tabel 3.

Tingkat keefektifan produk ditinjau dari keterlaksanaan produk apabila memperoleh skor 41,25-48,75 atau kategori efektif sedangkan keefektifan produk ditinjau dari hasil pengamatan aktivitas peserta didik apabilai memperoleh skor 27,50-32,50 atau kategori efektif. 


\section{Jurnal Prima Edukasia, 5 (1), January 2017 - 107}

Teguh Prasetyo

Selanjutnya untuk persentase ketuntasan prestasi belajar peserta didik KI-1, KI-2, KI-3, dan KI-4 secara klasikal ditetapkan $70 \%$.

\section{Hasil dan Pembahasan}

Hasil Penelitian

Tahap define dilakukan untuk menganalisis kebutuhan akan produk perangkat penilaian hasil belajar yang akan dikembangkan. Tahapan define meliputi: (1) analisis awalakhir, (2) analisis peserta didik, (3) analisis materi, (4) analisis tugas, dan (5) spesifikasi tujuan pembelajaran sebagai kajian teori secara konseptual untuk merancang draft perangkat penilaian. Berikut hasil analisis pada tahap define.

Kegiatan analisis awal-akhir dimaksudkan untuk menganalisis permasalahan yang dialami guru-guru kelas V SD terkait penilaian pembelajaran yang menggunakan Kurikulum 2013. Adapun hasil analisis pada kegiatan ini adalah guru membutuhkan perangkat penilaian yang praktis dan efektif digunakan dalam pembelajaran. Pengembangan perangkat penilaian tidak mudah bagi guru dalam membuat atau mengembangkan penilaian hasil belajar apabila tidak memiliki pemahaman tentang penilaian pembelajaran. Guru harus teliti dan cermat dalam memetakan beberapa KD-KD setiap mata pelajaran kemudian dijadikan lembar tugas pada kinerja untuk KI-4 dan penilaian tertulis untuk KI-3. Penilaian sikap spiritual (KI-1) dan sikap sosial (KI-2) dilakukan melalui lembar pengamatan sikap. Berdasarkan hasil wawancara dengan guru diperoleh informasi bahwa proses penilaian kompetensi sikap sementara dilakukan berdasarkan pengamatan selama pembelajaran di kelas mengenai sikap dan perilaku peserta didik selama subtema berlangsung. Selain itu ada juga yang membuat perangkat penilaian sikap ke dalam bentuk dokumentasi dengan menggunakan Microsoft excel yang digunakan sewaktu-waktu. Penilaian kompetensi keterampilan berupa tugas portofolio atau bentuk kinerja sesuai yang ada di Buku Siswa

Kegiatan analisis peserta didik lebih ditekankan pada kondisi dan lingkungan yang diamati peneliti terhadap peserta didik selama mengikuti pembelajaran di kelas. Aktivitas peserta didik yang ditemukan di SDN Godean 1 dan SDN Cebongan 1 memiliki kesamaan secara perkembangan fisik, sosial, dan kognitif. Santrok (2012, p.318) mengemukakan bahwa perkembangan fisik dan kognitif pada masa kanak-kanak pertengahan dan akhir mengalami pertumbuhan semakin tinggi, semakin berat, dan semakin kuat. Berdasarkan analisis dan kajian perkembangan peserta didik pada usia 10-12 tahun telah mengalami pertumbuhan dan perkembangan fisik dan kognitif. Anak-anak mulai mampu mengalami pertumbuhan dan perkembangan dalam bentuk fisik berat dan tinggi badan, mengalami perkembangan otak, dan mampu melakukan keterampilan motorik.

Analisis materi mencakup Kompetensi Inti (KI), Kompetensi Dasar (KD), dan indikator pencapaian hasil belajar yang diajarkan pada subtema tersebut. Berdasarkan tema Komponen Ekosistem kemudian dikembangkan berupa perangkat penilaian hasil belajar yang digunakan untuk pembelajaran. Perangkat penilaian hasil belajar terdiri; (1) penilaian sikap berupa lembar observasi sikap peserta didik, dan penilaian diri, (2) penilaian pengetahuan berupa tes uraian, dan (3) penilaian keterampilan berupa penilaian kinerja.

Pada tahap analisis tugas dilakukan sebagai berikut: (1) melakukan analisis SKL, $\mathrm{KI}, \mathrm{KD}$, dan membuat indikator pembelajaran, (2) membuat pemetaan KI, KD sesuai tema pembelajaran, (3) menyusun silabus dan RPP, dan membuat instrumen penilaian. Berikut ini disajikan KD-3 dan KD-4 pada subtema Komponen Ekosistem.

Tabel 4. Kompetensi Dasar IPA Kelas V SD

\begin{tabular}{cl}
\hline $\begin{array}{c}\text { Muatan } \\
\text { Mata } \\
\text { Pelajaran }\end{array}$ & \multicolumn{1}{c}{ Kompetensi Dasar } \\
\hline IPA & $\begin{array}{l}\text { 3.6. Mengenal jenis hewan dari } \\
\text { makanannya dan mendeskripsikan } \\
\text { rantai makanan pada ekosistem di } \\
\text { lingkungan sekitar } \\
\text { 4.6a. Menyajikan hasil pengamatan } \\
\text { untuk membentuk rantai makanan } \\
\text { dan jejaring makanan dari makhluk } \\
\text { hidup di lingkungan sekitar yang } \\
\text { terdiri atas karnivora, herbivora, dan } \\
\text { omnivora }\end{array}$ \\
\hline Pada & tahap spesifikasi tujuan pembel
\end{tabular}

Pada tahap spesifikasi tujuan pembelajaran merupakan hasil dari analisis materi dan analisis tugas pada subtema Komponen Ekosistem kelas V SD yang selanjutnya menjadi indikator pencapaian hasil belajar yang akan digunakan untuk mengembangkan perangkat penilaian hasil belajar. Adapun indikator pencapaian pembelajaran: (1) K1-3, mengenal jenis hewan dari makanannya dan mendeskripsikan komponen biotik dan abiotik, (2) KD.4.6, melakukan pengamatan untuk mengidentifikasi komponen di dalam sebuah ekosis- 
tem, (3) K-1, menunjukkan sikap bersyukur dengan menjaga lingkungan sekitar rumah, sekolah, dan masyarakat, (4) KI-2, menujukkan perilaku ilmiah teliti, percaya diri dan memiliki rasa ingin tahu dalam aktivitas sehari-hari sebagai wujud implementasi dalam melakukan inkuiri ilmiah dan berdiskusi (IPA).

Tahap design, dilakukan untuk menyesuaikan format, media, dan rancangan draft awal produk yang telah jadi. Pada tahap ini dipersiapkan media yang digunakan untuk mendukung penerapan perangkat penilaian hasil belajar yang dikembangkan. Media yang dipilih berupa slide power poin dan video tentang ekosistem. Adapun karakteristik draft produk awal perangkat penilaian hasil belajar sebagai berikut: (1) memuat konsep teoritis pengertian penilaian hasil belajar, lingkup penilaian hasil belajar, dan teknik penilaian hasil belajar pada kompetensi sikap, pengetahuan, dan keterampilan, (2) perangkat penilaian digunakan proses pembelajaran tematik integratif yang dilaksanakan di SD melalui pendekatan multi-disipliner, dimana perangkat penilaian yang dikembangkan fokus pada KD. IPA, (3) perangkat penilaian hasil belajar yang dikembangkan merupakan bagian yang tidak terpisahkan dari proses pembelajaran yang dilaksanakan guru di kelas, sehingga pembelajaran juga menerapkan pendekatan saintifik, (4) adapun empat teknik penilaian hasil belajar yang dikembangkan yaitu; (a) penilaian observasi sikap, (b) penilaian diri peserta didik, (c) tes uraian, dan (d) penilaian kinerja.

Selanjutnya tahap develop, merupakan fase uji coba yang meliputi validasi/penilaian ahli, dan uji coba pengembangan. Hasil penilaian tiga ahli dibidang asesmen pembelajaran dan pembelajaran di SD terhadap produk perangkat penilaian hasil belajar kelas V SD pada subtema Komponen Ekosistem, telah memenuhi kelayakan dengan kategori sangat baik. Hal ini diketahui dengan skor rata-rata validator mencapai 104. Namun ada ahli yang memberikan penilaian secara kualitatif yang disajikan secara deskriptif. Penilaian kelayakan dari ahil ini berarti produk secara konseptual perangkat penilaian telah layak digunakan di lapangan. Masukan dan saran ahli yang diberikan adalah (1) pernyataan pada penilaian diri masih sangat umum dan kurang mendetail, perlu diperbaiki, (2) indikator kurang sesuai dengan tema yang diajarkan, (3) jangan membuat indikator menjadi pernyataan salah, (4) KD ditekankan pada komponen ekosistem, tidak mengenal jenis hewan dan tumbuhan, revisi indikator ketiga pada perangkat penilaian pengetahuan.

Pelaksanaan uji coba pengembangan dilakukan melalui dua tahapan yakni uji coba terbatas dan uji coba lapangan. Adapun hasil pada uji coba terbatas dapat disajikan pada Tabel 5.

Tabel 5. Hasil Ujicoba Terbatas Perangkat Penilaian

\begin{tabular}{|c|c|c|}
\hline Aspek yang Dinilai & $\begin{array}{l}\text { Interval } \\
\text { Skor } \\
\text { Aktivitas }\end{array}$ & Kategori \\
\hline $\begin{array}{l}\text { 1. Kepraktisan guru (ob- } \\
\text { servasi sikap, penilai- } \\
\text { an diri, tes uraian, } \\
\text { penilaian kinerja) }\end{array}$ & $\begin{array}{c}24, \\
24,25,23\end{array}$ & $\begin{array}{l}\text { Sangat } \\
\text { Praktis }\end{array}$ \\
\hline $\begin{array}{l}\text { 2. Kepraktisan perangkat } \\
\text { penilaian berdasarkan } \\
\text { respon peserta didik }\end{array}$ & $70 \%$ & $\begin{array}{l}\text { Respon } \\
\text { Positif }\end{array}$ \\
\hline $\begin{array}{l}\text { 3. Keefektifan produk } \\
\text { dari keterlaksanaan }\end{array}$ & $43,47,5$ & $\begin{array}{l}\text { Sangat } \\
\text { Efektif }\end{array}$ \\
\hline $\begin{array}{l}\text { 4. } \begin{array}{l}\text { Keefektifan produk } \\
\text { berdasar } \\
\text { peserta didik }\end{array} \\
\text { aktivitas }\end{array}$ & 27,32 & $\begin{array}{l}\text { Sangat } \\
\text { Efektif }\end{array}$ \\
\hline \multicolumn{3}{|c|}{$\begin{array}{c}\text { Tabel 6. Hasil Ujicoba Lapangan } \\
\text { Perangkat Penilaian }\end{array}$} \\
\hline Aspek yang Dinilai & $\begin{array}{l}\text { Skor yang } \\
\text { Diperoleh }\end{array}$ & Kategori \\
\hline $\begin{array}{l}\text { 1. Kepraktisan guru (ob- } \\
\text { servasi sikap, penilai- } \\
\text { an diri, tes uraian, } \\
\text { penilaian kinerja) }\end{array}$ & $\begin{array}{c}27 \\
27,27,26\end{array}$ & $\begin{array}{l}\text { Sangat } \\
\text { Praktis }\end{array}$ \\
\hline $\begin{array}{l}\text { 2. Kepraktisan perang- } \\
\text { kat penilaian berda- } \\
\text { sarkan respon peserta } \\
\text { didik }\end{array}$ & $90 \%$ & $\begin{array}{l}\text { Sangat } \\
\text { Positif }\end{array}$ \\
\hline $\begin{array}{l}\text { 3. Keefektifan produk } \\
\text { dari keterlaksanaan }\end{array}$ & $50,48,53$ & $\begin{array}{l}\text { Sangat } \\
\text { Efektif }\end{array}$ \\
\hline $\begin{array}{l}\text { 4. } \begin{array}{l}\text { Keefektifan produk } \\
\text { berdasar } \\
\text { peserta didik }\end{array} \\
\text { aktivitas }\end{array}$ & $35,31,5,33$ & $\begin{array}{l}\text { Sangat } \\
\text { Efektif }\end{array}$ \\
\hline
\end{tabular}

Keterlaksanaan produk masih ditemukan hambatan seperti guru terkadang masih belum memahami rubrik penilaian khususnya pada penilaian kinerja. Adapun hasil uji coba memberikan masukan untuk penyempurnaan produk, yaitu: (a) petunjuk penggunaan penilaian baik yang digunakan guru maupun peserta didik, (b) revisi terutama pada soal tes uraian, (c) lembar penilaian kinerja agar ditambahkan kolom KD mana yang akan dinilai, (d) bahasa pada lembar kerja peserta didik perlu ada yang diperbaiki agar lebih mudah dipahami oleh peserta didik. Selanjutnya hasil pada uji coba terbatas akan menjadi acuan untuk revisi sebelum dilakukan 
uji coba operasional pada kelas dan sekolah yang berbeda. Adapun hasil uji coba lapangan produk perangkat penilaian pada pembelajaran tematik kelas V SDN Godean 1, SDN Cebongan 1, dan SDN 1 Purwomartani 1 pada Tabel 6.

Hasil penelitian juga memperoleh data ketuntasan prestasi belajar peserta didik yang meliputi kompetensi sikap spiritual (KI-1), sikap sosial (KI-2), pengetahuan (KI-3) dan keterampilan (KI-4). Adapun hasil ketuntasan di SDN Godean 1, SDN Cebongan 1, dan SDN Purwomartani 1 Pada uji coba lapangan juga diperoleh penilaian hasil belajar peserta didik pada penilaian kompetensi sikap spiritual (KI1) dan sikap sosial (KI-2), penilaian kompetensi pengetahuan (KI-3), dan penilaian kompetensi keterampilan (KI-4).

Ketuntasan peserta didik pada uji coba lapangan dapat disajikan pada Tabel 7.

Tabel 7. Hasil Ketuntasan Penilaian

\begin{tabular}{llcc}
\hline $\begin{array}{c}\text { Kompetensi yang } \\
\text { Dinilai }\end{array}$ & Tuntas & $\begin{array}{c}\text { Belum Tuntas/ } \\
\text { Bimbingan }\end{array}$ \\
\hline 1. kompetensi sikap & 94 & 15 \\
spiritual (KI-1) & $(86 \%)$ & $(14 \%)$ \\
2. kompetensi sikap & 92 & 17 \\
sosial (KI-2) & $(84 \%)$ & $(16 \%)$ \\
3. kompetensi & 86 & 23 \\
pengetahuan (KI-3) & $(79 \%)$ & $(21 \%)$ \\
4. kompetensi & 91 & 18 \\
& keterampilan (KI-4) & $(83,5 \%)$ & $(16,5 \%)$ \\
\hline
\end{tabular}

Pembahasan

Implementasi Kurikulum 2013 masih ditemukan kendala dalam proses penilaian pembelajaran. Kendala yang terjadi di lapangan adalah kesulitan dalam membuat perangkat penilaian yang digunakan untuk menilai proses dan hasil belajar oleh guru. Pelatihan-pelatihan yang dilalui guru belum cukup sehingga pemahaman guru masih terbatas. Adapun contohcontoh yang ada pada buku pegangan guru Kurikulum 2013 belum spesifik dan fokus pada materi atau tema yang ada pada KD mata pelajaran. Hal ini yang mendorong akan pentingnya perangkat penilaian yang layak, praktis, dan efektif dalam pembelajaran.

Pada tahap define, menganalisis kebutuhan perangkat penilaian dalam pembelajaran sangat penting bagi guru karena hal itu dapat membantu guru untuk mengevaluasi keefektifan pembelajaran yang dilaksanakan. Untuk itu penting bagi guru memiliki keterampilan, pemahaman, dan persepsi yang baik tentang penilaian pembelajaran. Penilaian akan menjadi tolak ukur dan menentukan hasil belajar yang dilakukan peserta didik di kelas. Pembelajaran tematik integratif di kelas kelas 4, 5, dan 6 SD proses penilaian tetap dilaksanakan sesuai muatan KD mata pelajaran yang diajarkan. Penilaian KD ini mencakup kompetensi sikap spiritual (KI-1), kompetensi sikap sosial (KI-2), kompetensi pengetahuan (KI-3), dan kompetensi keterampilan.

Pada tahap design, produk perangkat penilaian di SD perlu disesuaikan dengan materi belajar atau KD sesuai pembelajaran tematik kelas 4 SD. Selanjutnya draft perangkat penilaian hasil belajar dikembangkan dalam bentuk scenario pembelajaran. Penilaian pembelajaran yang menggunakan pendekatan saintifik yang meliputi kegiatan menanya, mengamati, mengolah informasi, menalar, dan mengomunikasikan. Adapun subtema Komponen Ekosistem yang dikembangkan sesuai dengan penilaian proses dan hasil belajar yang dilakukan peserta didik. Penilaian pada proses belajar peserta didik dilakukan pada saat mengamati komponen biotik dan abiotik dinilai menggunakan observasi sikap dan penilaian kinerja. Untuk mengetahui hasil belajar peserta didik dilakukan penilaian menggunakan tes uraian dan penilaian diri sebagai refleksi peserta didik.

Pada tahap develop, dilaksanakan kegiatan validasi ahli secara teoritik, uji coba terbatas, dan diperluas terhadap produk yang dikembangkan. Tujuan dilaksanakan vaslidasi dan ujicoba untuk mengetahui seberapa layak, praktis, dan efektif perangkat penilaian yang dihasilkan. Perangkat penilaian yang dikebangkan sesuai kompetensi sikap spiritual, sikap sosial, kompetensi pengetahuan, dan kompetensi keterampialan terdiri atas: (1) penilaian observasi sikap; (2) penilaian diri; (3) tes uraian; dan (3) penilaian kinerja.

Adapun pembahasan terkait produk pengembangan selama proses penilaian (validasi) oleh ahli asesmen pembelajaran dan ahli pembelajaran di SD menyatakan dapat digunakan dalam proses pembelajaran. Masukan dan saran ahli menjadi acuan untuk penyempurnaan produk dari segi kepraktisan seperti: (1) petunjuk penggunaan dipermudah; (2) kejelasan pedoman rubrik penilaian; dan (3) kemenarikan tampilan produk. Hasil analisis kelayakan produk dari ahli menunjukkan bahwa perangkat penilaian hasil belajar telah memiliki kajian teori secara konseptual. Kajian konseptual ini meliputi teori penilaian hasil belajar, konsep pembelajaran tematik, pendekatan saintifik, dan contoh pengembangan penilaian pada kompe- 


\section{Jurnal Prima Edukasia, 5 (1), January 2017 - 110 \\ Teguh Prasetyo}

tensi sikap, kompetensi pengetahuan, dan kompetensi keterampilan.

Analisis hasil uji coba pengembangan produk menunjukkan hasil kepraktisan produk sudah memenuhi kategori sangat praktis berdasarkan respon guru dan peserta didik. Untuk kategori keefektifan produk juga telah mencapai kategori sangat efektif berdasarkan keterlaksanaan produk dan hasil observasi aktivitas peserta didik. Hasil analisis uji coba pengembangan juga menunjukkan produk perangkat penilaian yang dihasilkan masih memiliki kekurangan pada kriteria kepraktisan produk. Hal ini terlihat respon guru dan peserta didik sebagai pengguna masih mengalami kesulitan khususnya pada perangkat penilaian kinerja. Dari segi keefektifan prestasi belajar peserta didik juga hanya dilakukan satu kali pengambilan data sehingga belum mengukur hasil belajar peserta didik yang optimal.

Volante (2006, p.136) mengemukakan bahwa ada tujuh prinsip untuk penilaian kelas yang efektif, yaitu: (1) kebutuhan untuk penilaian kelas menjadi berpusat pada siswa; (2) selaras dengan target pembelajaran yang jelas; (3) berdasarkan beberapa metode; (4) mampu menjelaskan berbagai keterampilan siswa; (5) bertujuan untuk mengurangi bias; (6) valid dan reliabel; dan (7) efisien. Pendapat Volante tersebut telah mendukung produk pengembangan perangkat penilaian hasil belajar yakni sesuai kebutuhan peserta didik, sesuai tujuan pembelajaran, mengukur keterampilan, valid dan efektif.

Kajian produk perangkat penilaian hasil belajar telah memenuhi kriteria perangkat penilaian yang baik sebagai berikut: (1) perangkat penilaian mengukur kompetensi sikap spiritual (KI-1), sikap sosial (KI-2), kompetensi pengetahuan (KI-3), dan kompetensi keterampilan (KI-4), (2) untuk pembelajaran kelas V SD pada subtema Komponen Ekosistem KD IPA (3) adanya teknik penilaian yang sesuai dengan kompetensi yang dinilai, (4) adanya tugas kinerja yang diberikan kepada peserta didik, (5) adanya pedoman acuan kriteria penilaian sesuai kompetensi yang diukur, dan (6) adanya kemudahan dalam pengadministrasian perangkat penilaian saat digunakan.

Berdasarkan pembahasan yang telah dikemukan di atas bahwa perangkat penilaian hasil belajar yang sudah dihasilkan baik secara teori maupun praktik teruji memiliki kriteria kelayakan, kepraktisan, dan keefektifan sehingga dapat digunakan untuk pembelajaran di kelas
V SD pada subtema Komponen Ekosistem. Hal senada diungkapkan oleh Setiani (2011, p.264) pengembangan asesmen atau penilaian pembelajaran yang baik harus memenuhi kriteria kevalidan, kepraktisan, dan keefektifan. Pada implementasinya produk perangkat penilaian hasil belajar yang mengukur $\mathrm{K} 1, \mathrm{~K} 2$, K3 dan K4 dapat dilaksanakan secara nyata di SD Piloting Projek Kurikulum 2013 di Kabupaten Sleman.

\section{Simpulan}

Berdasarkan hasil penelitian dan pengembangan perangkat penilaian hasil belajar untuk pembelajaran tematik di kelas V SD pada subtema Komponen Ekosistem dapat diperoleh kesimpulan sebagai berikut: (1) perangkat penilaian hasil belajar yang dikembangkan telah memenuhi kriteria layak digunakan, (2) perangkat penilaian hasil belajar yang dikembangkan telah memenuhi kriteria praktis berdasarkan respon guru dan peserta didik, (3) perangkat penilaian hasil belajar yang dikembangkan telah memenuhi kriteria efektif berdasarkan keterlaksanaan produk, observasi aktivitas peserta didik, dan ketuntasan penilaian KI-1, KI-2, KI3, dan KI-4.

\section{Daftar Pustaka}

Apriani, A., \& Wangid, M. (2015). Pengaruh ssp tematik-integratif terhadap karakter disiplin dan tanggung jawab siswa kelas iii sd. Jurnal Prima Edukasia, 3(1), 1225.

Retrieved fromhttp://journal.uny.ac.id/index.php/jp e/article/view/4061/3516

Anderson, L. W. (2008). Classroom assessment enhacing the quality of the teacher decision making. Mahwah, New Jersey: Lawrence Erlbaum Associates, Inc.

Arends, R. I., (2009). Learning to teach $9^{\text {th }}$ edition. New York: McGraw-Hill Companies

Earl, K., \& Giles, D., (2011). An-other Look at Assessment: Assessment in Learning. New Zealand Journal of Teachers' Work, Volume 8, Issue 1, halaman 11-20

Fogarty, R. (1991). The mindful school. how to integrate the curricula. Palatine: Skylight Publising Inc

Gronlund, N., Linn, R., \& Miller, M. (2009). Measurement \& evaluation in teaching $10^{\text {th }}$ edition. Upper Saddle River, New Jersey: Pearson Education Inc. 


\section{Jurnal Prima Edukasia, 5 (1), January 2017 - 111}

Teguh Prasetyo

Kemendibkud. (2013). Materi pelatihan guru implementasi kurikulum 2013 tahun 2014 sd kelas v. Jakarta: Kementrian Pendidikan dan Kebudayaan.

Kemendibkud. (2014). Peraturan Menteri Pendidikan dan Kebudayaan Republik Indonesia Nomor 66 tentang standar penilaian pendidikan.

Kemendibkud. (2014). Peraturan Menteri Pendidikan dan Kebudayaan Republik Indonesia Nomor 67 tentang kerangka dasar dan struktur kurikulum sekolah dasar/madrasah ibtidaiyah.

Kemendibkud. (2014). Peraturan Menteri Pendidikan dan Kebudayaan Republik Indonesia Nomor 104 tentang penilaian hasil belajar oleh pendidik pada pendidikan dasar dan menengah.

Kubiszyn, \& Borich. (2010). Educational and measurement: Classroom application and practice $9^{\text {th }}$ edition. Los Angeles: Sage Publication.

Majid, A. (2014). Implementasi kurikulum 2013 kajian teoritis dan praktis. Bandung: Interes Media.

Mardapi, D. (2012). Pengukuran, penilaian, dan evaluasi pendidikan. Yogyakarta: Nuha Medika.

National Quality Council (NQC). (2009). Guide for developing assessment tools. Australia: Department of the Education Employment and Wokplace Relations and State and Rerritory Goverments.

Nitko, A., \& Brookhart, S.M., (2011). Educational assessment of students $6^{\text {th }}$ edition. Boston, Mass.: Pearson Education

Reynolds, C. R., Livingston, R. B., \& Willson, V. (2010). Measurement and assessment in education. $2^{\text {th }}$ edition. Boston, MA: Pearson Educational International.

Santrock, J. W. (2012). Life-Span Development Perkembangan: Masa-Hidup. (Terjemahan Benedictine Widyasinta) (Buku asli diterbitkan Edisi Ketigabelas Jilid I 2011). Jakarta: Erlangga.

Setiani, F. (2012). Pengembangan asesmen alternatif dalam pembelajaran matematika dengan pendekatan realistik di sekolah dasar. Jurnal Penelitian dan Evaluasi Pendidikan PPs UNY. Nomor 2 Halaman 52-71

Stiggins, R. J., \& Chappuis, J. (2012). An introduction to student-involved assessment for learning $6^{\text {th }}$ edition. Boston: Pearson Education.

Subali, B. (2012). Prinsip asesmen \& evaluasi pembelajaran. Yogyakarta: UNY Press.

Thiagarajan, S., Semmel, D.S., \& Semmel, M.I. (1974). Instructional development for training teacher of exceptional children: A sourcebook. Minnesota: Central for Innovation on Teaching the Handicapped.

Volante, L., (2006). Principles for Effective Classroom Assessment. Des Lignes Directrices pour Une Évaluation Efficace en Salle de Classe. Brock Education. Volume 15, Nomor 2 halaman 134-147. 